Desi Marlina, Zikri Alhadil Kendala Pemerintah Kota Padang dalam Menanggulangi Bencana Abrasi Sepanjang Kawasan Pantai Purus di Kota Padang

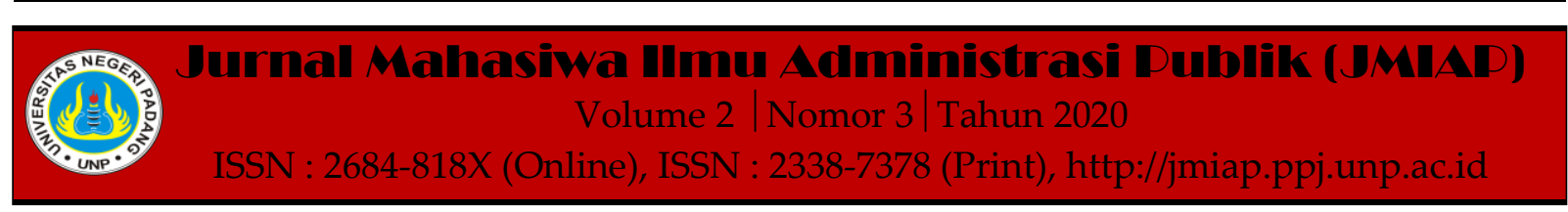

\title{
KENDALA PEMERINTAH KOTA PADANG DALAM MENANGGULANGI BENCANA ABRASI SEPANJANG KAWASAN PANTAI PURUS DI KOTA PADANG
}

\author{
Desi Marlina $^{1(a)}$, Zikri Alhadi $^{2(b)}$ \\ ${ }^{1}$ Jurusan Ilmu Administrasi Negara, Universitas Negeri Padang \\ ${ }^{2}$ Jurusan Ilmu Administrasi Negara, Universitas Negeri Padang \\ a)desimarlina772@gmail.com, ${ }^{b)}$ zikrialhadi@gmail.com
}

\begin{abstract}
Indonesian is a country that has very many islands and has the longest coastline after Canada. Of the many islands located in the territory of Indonesia, not all of the beaches are well preserved, even many of the beaches have suffered damage caused by coastal abrasion, one of which is the purus beach in the city of Padang. Abrasion is an erosion that often occurs in coastal areas caused by ocean waves over a long period of time and can also be caused by human activity itself. The purpose of this research is to determine the obstacles faced by the Padang city government in overcoming abrasion disasters along the purus beach area in the city of Padang. The results show that there are several obstacles that are being faced by the Padang city government in overcoming the abrasion disaster, namely the funds owned by the Padang city government are insufficient in carrying out abrasion disasters and the equipment used is also very limited so that the Padang city government in dealing with abrasion disasters on the coast purus according to the existing equipment.
\end{abstract}

Keywords : Constraints, Abrasion Management

Corresponding author. Email.desimarlina772@gmail.com,zikrialhadi@gmail.com

How to cite this article. Marlina, D \& Alhadi, Z. (2020). Kendala Pemerintah Kota Padang dalam Menanggulangi Bencana Abrasi Sepanjang Kawasan Pantai Purus di Kota Padang. Jurnal Mahasiwa Ilmu Administrasi Publik (JMIAP) Jurusan Ilmu Administrasi Negara Fakultas Ilmu Sosial Universitas Negeri Padang, Volume 2 (3), Hal. 9-15.

http://jmiap.ppj.unp.ac.id

ISSN : 2684-818X (Online), ISSN : 2338-7378 (Print)

Copyright $\bigcirc 2020$. Published by Labor Jurusan Ilmu Administrasi Negara FIS UNP, Padang 


\section{PENDAHULUAN}

Indonesia adalah Negara yang mempunyai kepulauan yang sangat banyak serta memiliki garis pantai yang paling panjang setelah Kanada. Dari sekian banyak nya pulau tersebut yang berada diwilayah Indonesia, namun tidak semua pantai itu terjaga dengan baik bahkan banyak dari pantai itu yang mengalami kerusakan yang disebabkan oleh Abrasi pantai. Ada beberapa kondisi pada kawasan pantai diIndonesia yang sangat mengkhawatirkan yang disebabkan dengan adanya kejadian abrasi ini salah satunya yaitu pantai purus yang berada di kota padang. Kondisi sepanjang pantai purus saat ini sangat mengkhawatirkan, jika dilihat dari bentuk kerusakan yang disebabkan oleh abrasi. Jika abrasi ini dibiarkan begitu saja bisa di pastikan kerusakannya semangkin parah dan tidak akan ada lagi yang namanya tugu merpati berada pantai tersebut. Maka dari itu diharapkan pemerintah kota padang bisa melakukan penanganan dengan cepat supaya tidak ada lagi kerusakan yang di sebabkan oleh abrasi ini. Abrasi ialah suatu pengikisan yang sering terjadi pada daerah pesisir yang disebabkan oleh arus pada gelombang laut pada batas waktu yang bisa dibilang agak cukup lamaa serta bisa juga disebabkan oleh ulah manusia itu sendiri.

Abrasi ini terjadi dapat juga di sebabkan oleh dua faktor yakni faktor alam dan faktor manusia. Proses abrasi yang diakibat kan oleh faktor alam ini yaitu berupa angin yang yang bertiup di lautan yang dapat menimbulkan arus gelombang laut sehingga arus gelombang tersebut memiliki kekuatan yang dahsyat untuk mengikis didaerah kawasan pantai itu. Sedangkan abrasi yang di sebabkan oleh ulah manusia ialah menebang pohon bakau yang berada di pantai dan melakukan penambangan pasir di wilayah pesisir pantai yang bisa mengakibatkan perubahan terhadap pola arus gelombang (Diposaptono 2011).

Kota Padang mempunyai garis pantai dengan panjang sekitar $18 \mathrm{~km}$ atau hampir $5 \%$ dari panjang total garis pantai di Sumatera Barat. Pada saat ini adapun bentuk permasalahan yang berkaitan dengan Pantai Padang ialah mundurnya pada garis pantai yang terjadi secara terus menerus yang akibatkan oleh gelombang arus laut. Saat ini Pantai purus yang berada di kota padang sering terjadinya abrasi pantai dalam waktu dua tahun terakhir ini. Abrasi pada pantai padang ini terjadi lagi pada bulan Juni 2019 di kawasan pantai padang Sumatra barat. Abrasi pantai padang khususnya di pantai purus sudah sangat memperhatinkan karena banyak kerusakan yang di sebabkan oleh abrasi seperti rusaknya Infrastruktur bangunan tugu merpati dan sempitnya tempat masyarakat untuk berdagang. Abrasi ini disebabkan oleh Ketinggian pasang air laut dan ombak besar yang menghantam dengan kekuatan yang dahsyat ke tepi pantai sehingga bisa menghancurkan yang berada di pinggir pantai tersebut. Sekarang ini pemerintah kota padang mengarahkan untuk melakukan penanggulangan abrasi di sepanjang kawasan pantai purus dikota padang.

Saat ini bibir pantai sudah menjorok kedaratan sepanjang 50 meter sehingga tidak aman lagi untuk masyarakat yang berjualan disekitar pantai tersebut. Abrasi ini juga mengakibatkan kerusakan kerusakan yang sangat parah tepatnya didekat tugu merpati. Tugu merpati yang saat ini berada di bibir pantai purus kota padang sudah terancam ambruk yang diakibatkan oleh abrasi dan mesjid yang berada di pinggir pantai purus tersebut juga mengalami kerusakan oleh abrasi ini. Jika dilihat dari bentuk ancaman abrasi ini adalah bentuk adalah bentuk ancaman yang bersifat permanen. kita dapat menyaksikan sendiri begitu kuat nya gelombang air laut ini menghantam ke tepi pantai. Jadi berdasarkan ancaman tersebut maka bentuk penanggulangan juga harus dilakukan secara permanen sehingga bencana abrasi ini bisa teratasi dengan baik.

Abrasi yang sering disebut juga dengan pengikisan pantai yang melanda di pantai purus tepatnya didekat tugu merpati kota padang, bukan hanya membuat garis yang berada pada bibir pantai itu berubah ukuran 
menjadi terlihat agak semangkin sempit. Namun jika dibiarkan seperti itu saja akibatnya pasti bisa berubah menjadi kearah yang sangat lebih berbahaya sehingga membuat kerusakan yang berada di sepanjang pantai tersebut. Seperti yang kita ketahui kota padang sangat populer dengan beragam keindahan pantai yang dimilikinya. Berbagai para wisatawan dari berbagai macam Negara didunia yang berkunjung kekota ini hanya untuk melihat keindahan pantainya saja. Apabila pantai ini sudah mengalami kerusakan yang diakibatkan oleh abrasi, maka dari itu tidak akan ada lagi para wisatawan uang berasal dari berbagai negara yang datang untuk mengunjunginya. Hal itu tersebut pastinya akan berdampak terhadap prekonomian mayarakat kota padang karena dari sector pariwisata itu sendiri telah mengalami penurunan pendapatan.

Maka dari itu dalam pelaksanaannya, penanganan masalah yang berkaitan dengan abrasi ini juga diperlukan untuk melibatkan berbagai kepentingan serta pemahaman terhadap bentuk pola penangananya. Untuk itu perlunya kerja sama antar stakeholder yang terkait dalam menanggulangi bencana abrasi. Tidak hanya kerja sama saja pembagian tugas dan kewenangan dalam melakukan penanggulangan abrasi pada daerah pantai tersebut juga harus jelas. Hal itu juga bertujuan supaya tidak terjadinya tumpang tindih antar masing-masing stakeholder yang terkait dalam melaksanakan kegiatan penanggulangan bencana abrasi sepanjang kawasan pantai purus di kota padang. Berdasarkan permasalahan yang terjadi sepanjang pantai purus di kota padang tersebut perlunya perhatian khusus dari pemerintah kota padang untuk menyikapi hal ini.

Berdasarkan latarbelakang yang peneliti paparkan diatas,oleh sebab itu peneliti tertarik untuk melaksanakan penelitian dengaan judul "Kendala Pemerintah Kota Padang Dalam Menanggulangi Bencana Abrasi Sepanjang Pantai Purus di Kota Padang."

\section{TINJAUAN PUSTAKA \\ Theory of Constraint}

Kendala merupakan factor yang menghalangi atau factor penghambat yang di hadapi oleh suatu instansi baik secara internal maupun secara eksternal. Kendala juga dapat membatasi system, baik instansi maupun organisasi dalam mencapai suatu tujuan dari instasi itu sendiri. Maka dari itu instasi tersebut harus mampu mengatasi kendala yang di hadapinya baik kendala yang berasal dari dalam instansi itu (internal) maupun kendala yang berasal dari luar instansi itu (eksternal) sehingga dalam melakukan pekerjaan bisa berjalan sesuai dengan yang diharapkan sebelumnya.

Dalam menanggulangi bencana abrasi di sepanjang kawasan pantai purus di kota padang ada beberapa kendala yang juga perlu ditangani, dikurangi secara cepat maupun dicegah oleh para stakeholder yang terkait dalam melakukan penanggulangan bencana abrasi tersebut. Dengan demikian, supaya tidak ada lagi hal yang bisa menghambat para stakeholder dalam melakukan penanggulangan abrasi ini.

Cox dan Schelier dalam Selviana dan Setya (2016:268) juga menyebut kan Theori Of Constrains yang lebih terkenal juga dengan sebutan TOC. TOC juga dapat di artikan sebagai sebuah pendekataan yang lebih menunjukan pada arah peningkatan suatu proses yang lebih difokus terhadap elemen-elemen yang dapat menghambat kinerjanya yang akan dilakukan oleh suatu instansi atau organisasi dalam meningkatkan outputnya.

Hansen dan Mowen dalam Selviana \& Setya (2016:23) menggolongkan berbagai macam kendala yang sudah terbagi menjadi kendala internal dan kendala ekstenal ialah sebagai berikut:

\section{Kendala internal}

Kendala internal ialah kendala yang menjadi faktor penghambat yang hanya berasal dari dalam instansi itu sendiri. Semua kendala yang berasal dari dalam instansi maka pihak instansi harus bisa mengatasi kendala tersebut supaya bisa 
melakukan pekerjaan nya dengan baik sesuai dengan apa yang sudah dirancang oleh instansi itu sebelumnya. Adapun bentuk kendala yang di temukan oleh pemerintah kota padang dalam menanggulangi bencana abrasi sepanjang kawasan pantai purus dikota padang merupakan suatu kendala yang berasal dari dalam instansi pemerintah kota padang tersebut. Jadi pemerintah kota padang harus bisa mengatasi kendala tersebut sehingga pekerjaan yang akan dilakukan nantinya bisa terlaksanakan dengan baik sesuai dengan yang sudah di rancang sebelumnya.

\section{Kendala Eksternal}

Kendala eksternal ini merupakan suatu kendala yang juga berasal dari luar instansi. Kendala yang berasal dari luar instansi ini juga dapat menghambat suatu pekerjaan yang akan dilakukan oleh instansi tersebut sehingga pekerjaan itu tidak berjalan sesuai dengan yang sudah ditetapkan sebelumnya. Disini pihak instansi harus bisa mengatasi kendala tersebut supaya nanti pekerjaan yang akan dilakukan bisa berjalan dengan lancar. Adapun kendala eksternal yang ditemukan dalam menanggulangi bencana abrasi di sepanjang kawasan pantai purus dikota padang adalah kendala yang terjadi dapat dikatakan berasal luar instansi pemerintah kota padang.

\section{METODE PENELITIAN}

Adapun jenis metode didalam penelitian yang akan di pakai ini untuk melakukan penelitian tersebut ialah Penelitian Kualitatif dengan metode deskriptif. Yang di sebut dengan penelitian kualitatif itu adalah sebuah prosedur penelitian yang dapat memberikan suatu data yang memiliki sifat deskriptif seperti kata yang berupa tertulis atau lisan yang di peroleh dari orang-orang yang telah di amati (Sugiyono, 2012:22). Sedangkan untuk menentukan informan, peneliti mengunakan teknik purposive sampling. Sedangkan untuk Teknik pengumpulan datanya yang peneliti pakai dalam melaksanakan penelitian tersebut ialah observasi, teknik wawancara, dan studi dokumentasi. Berdasarkan judul penelitian tersebut, maka lokasi penelitian akan dilakukan pada Kantor BPBD Kota Padang, Kantor BWS Sumatera V Provinsi Sumbar, Kantor Camat kota padang dan masyarakat di sekitar pantai purus di kota padang. Untuk melakukan uji keabsahan datanya peneliti memakai suatu teknik yang bisa di sebut dengan Triangulasi sumber. Sedangkan untuk teknik analisisnya datanya yang peneliti gunakan ialah dengan melakukan reduksi data, penyajian data, serta melakukan verifikasi data.

\section{HASIL DAN PEMBAHASAN \\ Kendala Pemerintah Kota Padang dalam Menanggulangi Bencana Abrasi Sepanjang Kawasan Pantai Purus di Kota Padang}

Berdasarkan hasil penelitian yang telah peneliti lakukan bahwa dalam melakukan penanggulangan bencana abrasi di Kota Padang dapat dilihat dari sejauh mana instansi tersebut untuk mencapai suatu tujuan dari kegiatan atau program yang telah ditetapkan semula oleh instansi agar dapat tercapai dengan baik. Dengan demikian apabila suatu kegiatan/program yang telah dirancang oleh suatu instansi tersebut dapat mencapai suatu sasaran yang telah ditentukan sebelumnya maka sudah bisa dibilang program tersebut sudah dapat dikatakan efektif, namun sebaliknya jika suatu kegiatan yang telah dirancang sebelumnya tidak mencapai tujuan yang telah ditetapkan sebelumnya maka kegiatan tersebut tidak dapat dikatakan efektif.

Pemerintah kota padang sudah melakukan beberapa bentuk penanggulangan bencana abrasi yaitu Pertama pemerintah kota padang sudah melakukan pemasangan batu penanggkalan ombak yang menjorok ketepi pantai. Menurut peneliti pemasangan batu pemasangan batu penanggkal ombak tersebut tidak efektif karena dengan di pasangan nya batu penangkal tersebut bisa membahayakan pemduduk kota padang jika suatu saat terjadi gempa yang berpotensi 
tsunami maka batu tersebutlah yang pertama kali memporak porandakan penduduk kota padang. maka dari itu pemerintah kota padang dalam melakukan penanganan bencana abrasi sepanjang pantai purus harus melihat terlebih dahulu dampak nya yang akan muncul terhadap masyarakat kota padang. Kedua Pemerintah kota padang melakukan pemasangan karung yang berisi pasir. jika kita melihat kerusakan yang disebabkan oleh abrasi ini sangat parah dan pemerintah kota padang tidak bisa hanya menghandalkan pemasangan pasir dalam karung saja melainkan pemerintah kota padang harus melakukan penanggulangan abrasi permanen sehingga abrasi ini bisa diatasi. Menurut peneliti, pemasangan karung dalam pasir ini kurang efektif karena dengan hanya memasang tumpukan karung yang berisi pasir yang sewaktu-waktu tumpukan karung tersebut akan di bawa oleh ombak besar. Ketiga melakukan penanaman pohon bakau di sepanjang pantai pantai purus dikota padang. jika kita lihat di sepanjang pantai purus dikota padang itu belum ada satupun pohon bakau yang sudah di tanam oleh pemerintah kota padang, jadi dalam melakukan penanganan abrasi dengan melakukan penanaman pohon bakau ini tidak efektif karena belum ada nya dari pemerintah kota untuk melakukan penanaman pohon bakau tersebut.

Jadi dapat peneliti simpulkan bahwa dalam menanggulangi bencana abrasi sepanjang kawasan pantai purus di kota padang dapat dikatakan belum efektif karena kinerja pemerintah kurang optimal dalam menanggulangi bencana abrasi.

\section{Kendala Internal}

Kendala eksternal ini merupakan suatu kendala yang juga berasal dari dalam organisasi. Semua kendala yang berasal dari dalam instansi maka pihak instansi harus bisa mengatasi kendala tersebut supaya bisa melakukan pekerjaan nya dengan baik sesuai dengan apa yang sudah dirancang oleh instansi itu sebelumnya. Dalam menanggulangi bencana abrasi di sepanjang kawasan pantai purus dikota padang kendala yang terjadi dapat dikatakan berasal dalam organisasi pemerintah kota padang.

Dari hasil penelitian dapat dilihat bentuk kendala internal yang di hadapi oleh pemerintah kota padang ialah Seperti yang kita lihat kerusakan yang disebabkan oleh abrasi ini sangat parah, maka perlu penanganan yang bersifat permanen. jadi yang menjadi kendalanya yaitu, yang pertama berkaitan dengan dana, dana yang dimiliki pemerintah kota padang untuk saat ini tidak mencukupi dalam melakukan penanggulangan bencana abrasi yang bersifat permanen. Yang kedua yaitu berkaitan dengan peralatan, peralatan yang digunakan yaitu berupa karung. dalam pemasangan karung yang berisi pasir tersebut yang menjadi kendalanya adalah stok karung yang dimiliki itu juga terbatas. Karung yang gunakan itu bukan karung biasa tapi karung yang khusus yang tidak mudah hancur kena air. Kemudian BPBD minta lagi karung tersebut ke provinsi mereka bilang stoknya sudah tidak ada lagi. Jadi peralatan yang dimiliki untuk saat ini juga sangat terbatas sehingga pemerintah kota padang dalam menanggulangi bencana abrasi di pantai purus hanya melakukan penanggulangan abrasi sepanjang pantai purus di kota padang juga sesuai dengan peralatan yang ada.

Disini peran dari masing-masing stakeholder sangat di perlukan untuk melakukan penanggulangan bencana abrasi ini. Maka dari itu masing-masing stakeholder yang terlibat harus bisa mengatasi kendala tersebut agar bisa melakukan pekerjaannya sesuai dengan apa yang sudah di tentukan sebelumnya. Disini peran dari masing-masing stakeholder sangat di perlukan untuk melakukan penanggulangan bencana abrasi ini.

Jadi berdasarkan teori yang di paparkan oleh para ahli tersebut yaitu Hansen \& Mowen yang terdapat didalam Selviana dan Setya.(2016:23) mengungkapkan apa yang dimaksud dengan kendala internal (Internal 
Desi Marlina, Zikri Alhadi I Kendala Pemerintah Kota Padang dalam Menanggulangi Bencana Abrasi Sepanjang Kawasan Pantai Purus di Kota Padang

Constraint) ialah salah satu faktor yang dapat membatasi suatu instansi yang berasal dari dalam instansi tersebut.

\section{Kendala Eksternal}

Kendala eksternal ini merupakan suatu kendala yang juga berasal dari luar organisasi. Adapun kendala yang di hadapi oleh pemerintah kota padang dalam menanggulangi bencana abrasi di sepanjang kawasan pantai purus dikota padang adalah bentuk kendala yang terjadi dapat dikatakan berasal dalam organisasi pemerintah kota padang. dilihat dari hasil penelitian menunjukan bahwa yang menjadi kendala eksternalnya yang di hadapi oleh pemerintah kota padang ialah. Yang pertama Ketika pemerintah kota padang melakukan pemasangan batu bergonjong ke arah laut, itu sangat berpengaruh terhadap angin, maka terjadi lah penolakan dari nelayan. Karna dengan memasang batu bergonjong tersebut para nelayan akan kesusahan menarik perahunya kedaratan. Yang kedua permasalahan social ,karena mengingat bencana abrasi yang berada di tengah-tengah pusat kota padang. Maka dari itu sebelum melakukan pekerjaan masing-masing stakeholder terlebih dahulu harus melakukan sosialisasi atau pendekatan kepada masyarakat sehingga nantinya pekerjaan yang akan dilaksanakan bisa berjalan dengan lancar tanpa adanya hambatan.

Berdasarkan dengan teori yang telah dikemukakan oleh Hansen\&mowen dalam selviana\&setya (2016:23) mengatakan apa yang dimaksud dengan kendala ekssternal ( eksternal constrainst). Yaitu merupakan Salah satu factor yang dapat membatasi kinerja suatu instansi yang berasal dari luar instansi tersebut. Atau bisa juga di katakan sebagai suatu kendala yang berasal dari luar instansi tersebut.

\section{PENUTUP}

Kendala merupakan salah factor yang dapat menghalangi atau factor penghambat yang di hadapi oleh suatu instansi baik secara internal maupun secara eksternal.
Sebelumnya Pemerintah kota padang sudah melakukan beberapa bentuk penanggulangan bencana abrasi yaitu Pertama pemerintah kota padang sudah melakukan pemasangan batu penanggkalan ombak yang menjorok ketepi pantai. Kedua Pemerintah kota padang melakukan pemasangan karung yang berisi pasir. Ketiga melakukan penanaman pohon bakau di sepanjang pantai pantai purus dikota padang. Hansen dan Mowen dalam Selviana \& Setya (2016:23) menggolongkan berbagai macam kendala yang sudah terbagi menjadi kendala internal dan kendala ekstenal ialah sebagai berikut: Kendala internal ialah kendala yang menjadi faktor penghambat yang hanya berasal dari dalam instansi itu sendiri. Semua kendala yang berasal dari dalam instansi maka pihak instansi harus bisa mengatasi kendala tersebut supaya bisa melakukan pekerjaan nya dengan baik sesuai dengan apa yang sudah dirancang oleh instansi itu sebelumnya. Adapun bentuk kendala yang di temukan oleh pemerintah kota padang dalam menanggulangi bencana abrasi sepanjang kawasan pantai purus dikota padang merupakan suatu kendala yang berasal dari dalam instansi pemerintah kota padang tersebut.

Adapun yang menjadi kendala internal yang sedang dialami oleh pemerintah kota padang dalam menanggulangi bencana abrasi sepanjang kawasan pantai purus dikota padang yang pertama, yaitu dana yang dimiliki pemerintah kota padang tidak mencukupi dalam melakukan penanggulangan bencana abrasi dan peralatan yang digunakan juga sangat terbatas sehingga pemerintah kota padang dalam menanggulangi bencana abrasi di pantai purus sesuai dengan peralatan yang ada.

Kendala eksternal ini merupakan suatu kendala yang juga berasal dari luar instansi. Kendala yang berasal dari luar instansi ini juga dapat menghambat suatu pekerjaan yang akan dilakukan oleh instansi tersebut sehingga pekerjaan itu tidak berjalan sesuai 
Desi Marlina, Zikri Alhadi I Kendala Pemerintah Kota Padang dalam Menanggulangi Bencana Abrasi Sepanjang Kawasan Pantai Purus di Kota Padang

dengan yang sudah ditetapkan sebelumnya. Disini pihak instansi harus bisa mengatasi kendala tersebut supaya nanti pekerjaan yang akan dilakukan bisa berjalan dengan lancar.

Adapun yang menjadi kendala eksternal yang sedang dialami oleh pemerintah kota padang dalam menanggulangi bencana abrasi sepanjang kawasan pantai purus dikota padang yang pertama yaitu permasalahan social, sebelum melakukan pekerjaan mereka terlebih dahulu harus melakukan sosialisasi atau pendekatan kepada masyarakat sehingga nantinya pekerjaaan yang akan dilakukan dapat berjalan dengan baik. Yang kedua, yaitu Ketika pemerintah kota padang melakukan pemasangan batu bergonjong ke arah laut, itu sangat berpengaruh terhadap angin, maka terjadi lah penolakan dari nelayan. Karna dengan memasang batu bergonjong tersebut para nelayan akan kesusahan menarik perahunya kedaratan

\section{DAFTAR KEPUSTAKAAN}

Bambang Triatmodjo, 1999, Teknik Pantai, Beta Offset, Yogyakarta.

Diposaptono, S. 2011. Mitigasi Bencana dan Adaptasi Perubahan Iklim. Kementrian Kelautan dan Perikanan, Direktorat Kelautan dan Pesisir dan Pulau-Pulau Kecil. Jakarta
Hansen, \& Mowen. (2007). Managerial Accounting (8th ed.). New York: McGraw-Hill.

Moleong.J Lexy. 2006. Metodelogi Penelitian Kualitatif (Ed.rev). Bandung

PT.Remaja Rosda karya Bandung.

Nurjanah, dkk. 2011. Manajemen Bencana. Jakarta: Alfabeta.

Pratikto, W.A., Haryo. D.A, Suntoyo., (2007), Perencanaan Fasilitas Pantai dan Laut, Yogyakarta: BPFE Yogyakarta.

Ramli, Soehatman. 2010.Pedoman Praktis Manajemen Bencana (Disaster Management). Jakarta: PT. Dian Rakyat.

Selviana Putri Larasati, Setya Haksama. 2016. Penerapan Theory of Constraint Pada Kepuasan Kerja Karyawan Rumah Sakit Mata Undaan Surabaya. Jurnal Administrasi Kesehatan Indonesia Vol. 4 No. 2

Sugiyono. 2008. Metode Penelitian Kualitatif Kuantitatif dan $R \& D$. Bandung: Alfabeta

Sugiyono. 2012. Metode Penelitian Kombinasi. Bandung: Alfabeta. 